НАУКОВИЙ ВІСНИК

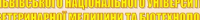

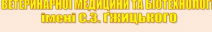

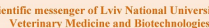

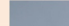

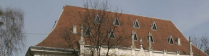
11) IIIMI

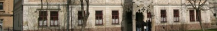

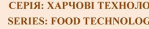
Том 23 № 95 2021
Науковий вісник Львівського національного університету ветеринарної медицини та біотехнологій імені С.3. Гжицького. Серія: Харчові технології

Scientific Messenger of Lviv National University of Veterinary Medicine and Biotechnologies.

Series: Food Technologies

UDC 637.138

\title{
Physico-chemical indicators of kefir with biologically active iodine in the process of fermentation
}

\author{
D. Ya. Dalievska, O. S. Pokotylo
}

Ternopil Ivan Puluj National Technical University, Ternopil, Ukraine

Article info

Received 25.01.2021

Received in revised form 25.02.2021

Accepted 26.02.2021

Ternopil Ivan Puluj National Technical University, Department of Food Technologies,

Ruska Str., 56, Ternopil.

46001, Ukraine.

Tel.: +38-097-211-02-57

E-mail: dalievska.d@gmail.com
Dalievska, D. Ya., Pokotylo, O. S. (2021). Physico-chemical indicators of kefir with biologically active iodine in the process of fermentation. Scientific Messenger of Lviv National University of Veterinary Medicine and Biotechnologies. Series: Food Technologies, 23(95), $72-77$. doi: $10.32718 /$ nvlvet-f9512

Iodine is a natural trace element that is necessary for the human body. The function of iodine in the human body is the synthesis of thyroid hormones. Iodine deficiency has many negative consequences for the human body. Iodine deficiency is especially dangerous for pregnant women and children. Insufficient iodine in pregnant women increases the risk of miscarriage and birth of a child with cognitive impairment. Iodine deficiency in children has the following consequences: delayed physical development, delayed intellectual development, decreased mental activity, drowsiness, lethargy. Expanding food with iodine is a necessary step to overcome the problem of iodine deficiency. The quality of dairy products in Ukraine is very high. Due to the mandatory implementation of the HACCP system, manufacturers are improving equipment and production technologies. Accordingly, the requirements for the quality of raw materials increase in proportion to the competitiveness of the enterprise. That is why it is important to develop dairy products that will be in demand among consumers.Kefir with a biologically active additive "Iodis-concentrate" is a source of the required amount of iodine for the body. Jodis-concentrate is a certified biologically active additive that is widely used in the food industry. It has already found application in water production and the meat industry. The article presents a comparative analysis of changes in titrated acidity and active acidity $(\mathrm{pH})$ in control and experimental samples of kefir during fermentation with the addition of biologically active iodine. The source of iodine was a biologically active additive "Iodis-concentrate". It is shown that the titrated acidity in both samples of kefir - control and experimental - had the same dynamics before growth during fermentation, which indicates no effect of the addition of biologically active iodine on the dynamics of titrated acidity. The same tendency to decrease the active acidity (pH) in control and experimental samples of kefir during fermentation with a difference within the significant error, indicating no effect of adding biologically active iodine to kefir on active acidity $(\mathrm{pH})$.

Key words: kefir, biologically active iodine, fermentation, titrated acidity, active acidity.

\section{Фізико-хімічні показники кефіру з біологічно активним йодом в процесі сквашування}

\author{
Д. Я. Далєвська, О. С. Покотило
}

Тернопільський національний технічний університет імені Івана Пулюя, м. Тернопіль, Украӥна

Розширення продуктів харчування з йодом є необхідним кроком для подолання проблеми йододефіциту. Якість молочної продукиії в Україні дуже висока. Завдяки обов'язковому впровадженні системи НАССР підприємства-виробники покращують обладнання та технологї виробництва. Відповідно вимоги до якості сировини зростають пропориійно конкурентоспроможності підприємства. Саме тому важливим є розробка молочної продукиії, яка буде користуватися попитом у споживачів. Кефір з біологічно активною добавкою “Йодіс-кониентрат” є джерелом необхідної кількості йоду для організму. “Йодіс-кониентрат” - ие сертифікована біологічно активна добавка, яка широко використовується в харчовій промисловості. Своє застосування вона знайшла вже у виробництві води та м'ясній промисловості. Метою даної роботи було дослідити динаміку змін окремих фізико-хімічних показників (титровану кислотність та водневий показник) кефіру, до якого додавали біологічно активний йод в процесі сквашу- 
вання. Дослідження фізико-хімічних показників зразків кефіру проводилися в лабораторії технології молока і молочних продуктів на кафедрі харчової біотехнологї $і$ хімії Тернопільського начіонального технічного університету імені Івана Пулюя. В статті подано порівняльний аналіз змін титрованої кислотності та активної кислотності (рН) у контрольних і дослідних зразках кефіру в прочесі сквашування при додаванні біологічно активного йоду. Джерелом йоду послужила біологічно активна добавка “Йодісконцентрат”. Показано, щзо титрована кислотність в обох зразках кефіру - контрольному і дослідному - мала однакову динаміку до зростання в прочесі сквашування, щуо свідчить про відсутність впливу додавання біологічно активного йоду на динаміку титрованої кислотності. Встановлена однакова тенденція зменшення активної кислотності (рН) у контрольних і дослідних зразках кефіру в прочесі сквашування із різницею в межах достовірної похибки, щчо свідчить про відсутність впливу додавання біологічно активного йоду до кефіру на активну кислотність (рН). Встановлено, щзо біологічно активна добавка “Йодіс-концентрат”" не впливає на в 'язкість кефіру. Також встановлено, щуо біологічно активний йод в складі добавки “Йодіс-концентрат” не впливає на масову частку жиру.

Ключові слова: кефір, біологічно активний йод, сквашування, титрована кислотність, активна кислотність.

\section{Вступ}

Кефір - це кисломолочний продукт змішаного молочнокислого та спиртового бродіння, який виробляють сквашуванням молока симбіотичною кефірною закваскою на кефірних грибках або концентратом грибкової кефірної закваски (DSTU 4417; Nagovska et al., 2018; Haidei et al., 2020). Кефip відіграє важливу роль у харчуванні людини, оскільки має добре виражені харчові, дієтичні, лікувальні та лікувальнопрофілактичні властивості (Ctarovoitova, 2017; Nahovska et al., 2017). Завдяки цим властивостям він краще засвоюється організмом і часто рекомендується хворим, які мають розлади шлунково-кишкового тракту. Кефір містить у легкозасвоюваній формі багато корисних речовин, які утворилися в процесі життєдіяльності мікроорганізмів. Молочнокисла мікрофлора кефіру $є$ антагоністом гнильної й патогенної мікрофлори (Ctarovoitova, 2017; Yukalo et al., 2019).

Важливим аспектом повноцінного харчування $\epsilon$ належне забезпечення організму мікроелементами. Тривалий дефіцит окремих цих ессенціальних речовин може призвести до серйозних наслідків (Nechyporuk \& Korda, 2015; Kopchak et al., 2018). Відомий мікроелемент Йод $є$ офіційно визнаним як ендемічно дефіцитний у понад 150 країнах, в тому числі в Україні (Nechyporuk \& Korda, 2015). Дефіцит цього елемента в раціоні викликає серйозні порушення у метаболізмі майже всіх органів і не залежить від віку (Nechyporuk \& Korda, 2015; Kopchak et al., 2017). Адже відомо, що йод необхідний для синтезу тироїдних гормонів, які регулюють цілий комплекс біохімічних процесів в організмі. Ці гормони особливо важливі в дитячому організмі, оскільки підтримують рівень метаболізму, чим забезпечують їх нормальний ріст і розвиток (Norouzian, 2011; Soriguer et al., 2011; Nechyporuk \& Korda, 2015). Дослідження, проведені ВООЗ за останні роки у різних країнах світу, показали, що рівень розумового розвитку (коефіцієнт інтелекту IQ) пов'язаний з йодом. Так, значення цього показника у населення, що проживає в регіонах з йодною недостатністю, на 15-20\% нижчі, ніж у регіонах без дефіциту йоду (Sojustova et al., 2009). Прояви йододефіциту наступні: зниження пам'яті, сонливість, дратівливість, зниження уваги та інтелекту.

В традиційному раціоні українців недостатньо продуктів, які здатні забезпечити необхідне надходження Йоду в організм. Тому створення нових функціональних продуктів, які б могли вирішити цю проблему, залишається актуальним завданням. В Україні вже розроблено i впроваджено окремі функціональні продукти із додатковим вмістом йоду, в тому числі й молочні. Проте їх арсенал $\epsilon$ недостатнім для забезпечення попиту населення і вирішення проблеми йододефіциту в населення.

Виходячи із сказаного вище, метою даної роботи було дослідити динаміку змін фізико-хімічних показників (титровану кислотність, активну кислотність, в'язкість, масову частку жиру) кефіру, до якого додавали біологічно активний йод в процесі сквашування.

\section{Матеріал і методи досліджень}

Дослідження фізико-хімічних показників зразків кефіру проводилися в лабораторії технології молока i молочних продуктів на кафедрі харчової біотехнології і хімії Тернопільського національного технічного університету імені Івана Пулюя. Для аналізу використали 2 види кефіру: контрольний (кефір без добавок) та дослідний кефір $з$ добавкою біологічно активного йоду. Джерелом служила відома сертифікована добавка "Йодіс-концентрат". (ТУ у 14326060.003-98; Solving the problem of iodine deficiency: "JodisConcentrate"). Розрахункова доза йоду взята 3 рекомендацій ВООЗ. Кількість зразків, які бралися для дослідження кожного виду кефіру, була кратною 5.

Важливою складовою достовірних досліджень $є$ контроль продукту на кожному етапі технологічного процесу. Показники, за якими визначалися фізикохімічні показники контрольної та дослідної проб, на кожному технологічному етапі наведені в таблиці 1.

\section{Таблиця 1}

Схема дослідження зразків

\begin{tabular}{cc}
\hline $\begin{array}{c}\text { Етап технологічного } \\
\text { процесу }\end{array}$ & Досліджувані фізико- \\
хімічні показники \\
\hline & Масова частка жиру $(\%)$ \\
Вустина $\left(\right.$ кг $\left./ \mathrm{M}^{3}\right)$ \\
Внесення закваски & Температура $\left({ }^{\circ} \mathrm{C}\right)$ \\
& Титрована кислотність $\left({ }^{\circ} \mathrm{T}\right)$ \\
& Активна кислотність $(\mathrm{pH})$ \\
& Ефективність пастеризації \\
\hline \multirow{2}{*}{ Сквашування } & Температура $\left({ }^{\circ} \mathrm{C}\right)$ \\
& Титрована кислотність $\left({ }^{\circ} \mathrm{T}\right)$ \\
& Активна кислотність $(\mathrm{pH})$ \\
\hline
\end{tabular}

Всі методи дослідження проводилися згідно 3 методиками, які регламентуються чинними норматив- 
ними документами. Відповідність нормативних документів досліджуваним показникам наведено в таблиці 2.

\section{Таблиця 2}

Відповідність нормативних документів методикам дослідження кефіру

\begin{tabular}{lc}
\hline \multicolumn{1}{c}{ Етап або показник } & Чинний нормативний \\
дослідження & документ \\
\hline Відбір проб & ДСТУ ISO 707 \\
Масова частка жиру $(\%)$ & ДСТУ ISO 1211 \\
Густина $\left(\right.$ кг $\left./ \mathrm{m}^{3}\right)$ & ДСТУ 6082 \\
Температура $\left({ }^{\circ} \mathrm{C}\right)$ & ДСТУ 6066 \\
Титрована кислотність $\left({ }^{\circ} \mathrm{T}\right)$ & ГОСТ 3624 \\
Активна кислотність $(\mathrm{pH})$ & ДСТУ 8550 \\
Ефективність пастеризації & ДСТУ 7380 \\
\hline
\end{tabular}

\section{Результати дослідження}

Дослідження відібраних зразків починали із аналізу молока ТМ Молокія, яка виступала сировиною для виробництва кефіру. Показники, за якими контролювали молоко, наведені у таблиці 1. Результати фізико-хімічних показників молока-сировини наведено в таблиці 3.

Заквашувальною культурою виступала кефірна закваска прямого внесення, яка складалася 3 дріжджів (лактозозброджувальні Kluyveromyces marxianus та ті, що не ферментують лактозу, Saccharomyces unisporus, Saccharomyces cerevisiae i Saccharomyces exiguus); гомо- і гетероферментативних молочнокислих коків роду Lactococcus, Leuconostoc, молочнокислі палички Lactobacillus kefiri, Lactobacillus casei, оцтовокислі бактерії Acetobacter aceti. Після внесення закваски ми спостерігали за наростанням титрованої кислотності $\left({ }^{\circ} \mathrm{T}\right)$, активної кислотності (pH) та здійснювали контрольні заміри температури. Усі зразки сквашувалися при температурі $30-31{ }^{\circ} \mathrm{C}$.

\section{Таблиця 3}

Фізико-хімічні показники молока-сировини

\begin{tabular}{lc}
\hline \multicolumn{1}{c}{ Показник молока-сировини } & Результат дослідження \\
\hline Масова частка жиру $(\%)$ & 2,5 \\
Густина $\left(\kappa г / \mathrm{m}^{3}\right)$ & 1,028 \\
Температура $\left({ }^{\circ} \mathrm{C}\right)$ & 6 \\
Титрована кислотність $\left({ }^{\circ} \mathrm{T}\right)$ & 18 \\
Активна кислотність $(\mathrm{pH})$ & 6,67 \\
Ефективність пастеризації & Фосфатаза - відсутня, \\
\hline
\end{tabular}

Отримані результати щодо динаміки наростання титрованої кислотності у контрольних зразках кефіру наведені на рис. 1.

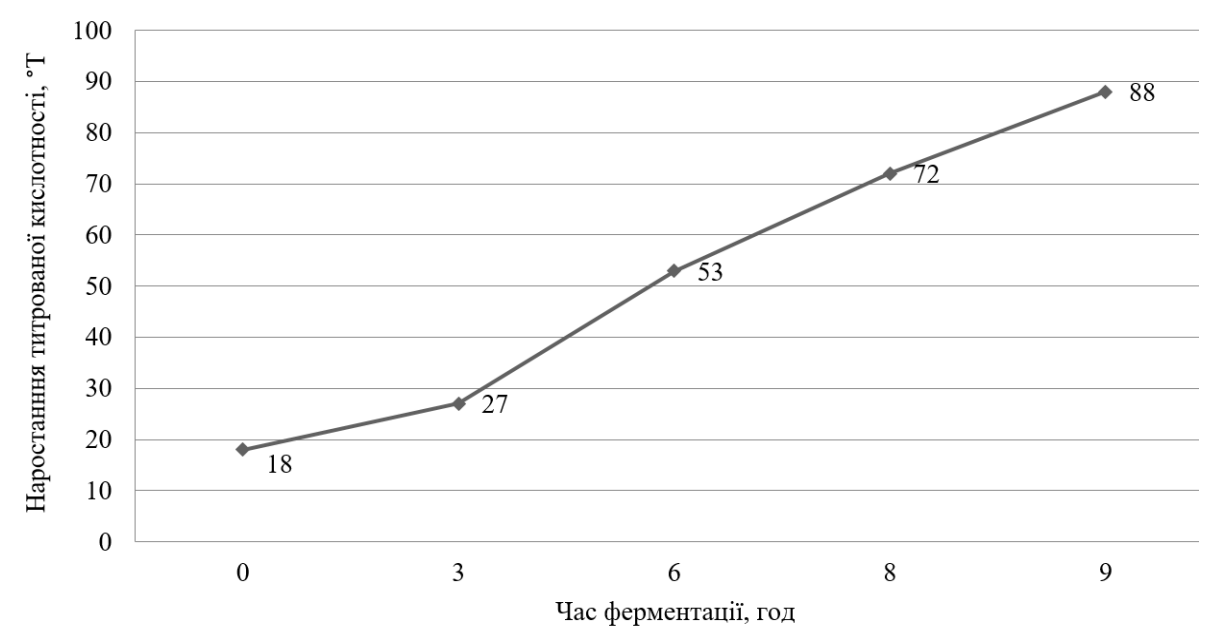

Рис. 1. Зміна титрованої кислотності у контрольних зразках кефіру, впродовж процесу ферментації, ${ }^{\circ} \mathrm{T}$

$$
(\mathrm{M} \pm \mathrm{m}, \mathrm{n}=5)
$$

Як видно із даних, наведених на рис. 1, встановлено інтенсивне наростання титрованої кислотності в контрольних пробах у процесі ферментації за 9 годин. Так, на початку дослідження титрована кислотність становила $18^{\circ} \mathrm{T}$, а через 9 годин зросла до $88^{\circ} \mathrm{T}$, тобто збільшилася на $60^{\circ} \mathrm{T}$, або 79,5\%.

Результати дослідження динаміки наростання титрованої кислотності ( $\left.{ }^{\circ} \mathrm{T}\right)$ у дослідному варіанті кефіру 3 добавкою "Йодіс-концентрат” наведено на рис. 2.

Згідно з даними, наведеними на рис. 2, встановлено також інтенсивне наростання титрованої кислотності ( $\left.{ }^{\circ} \mathrm{T}\right)$ під час процесу сквашування в досліджуваних пробах кефіру, до якого додавали біологічно ак- тивний йод. Максимальне значення показника титрованої кислотності зафіксовано через 9 годин сквашування, тобто в кінці експерименту дослідження, і воно становило $89^{\circ}$ Т. Як видно із даних рис. 1 і 2 , титрована кислотність в обох серіях зразків кефіру - контрольного і дослідного мала однакову динаміку. Отримані результати свідчать, що додавання біологічно активного йоду не впливає на динаміку титрованої кислотності, що має позитивне значення.

На рис. 3 показані результати дослідження активної кислотності (рН) у контрольних пробах кефіру впродовж процесу сквашування. 


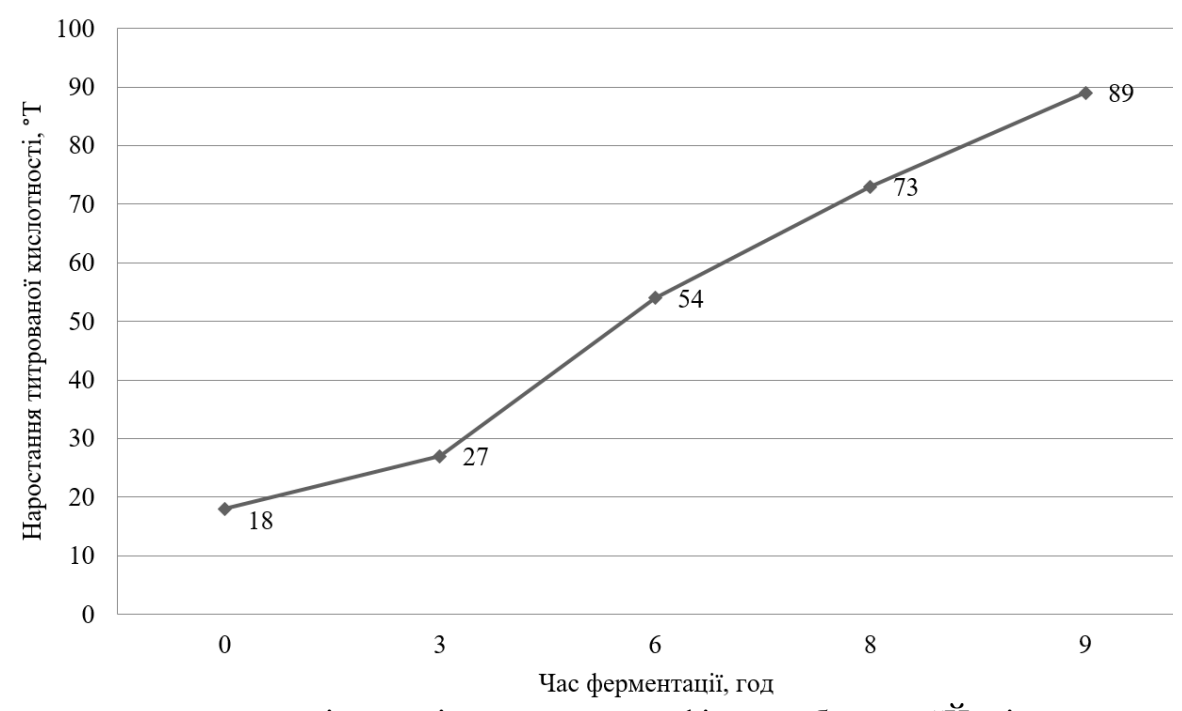

Рис. 2. Зміна титрованої кислотності у дослідних зразках кефіру з добавкою “Йодіс-концентрат”, впродовж процесу ферментації, ${ }^{\circ} \mathrm{T}(\mathrm{M} \pm \mathrm{m}, \mathrm{n}=5)$

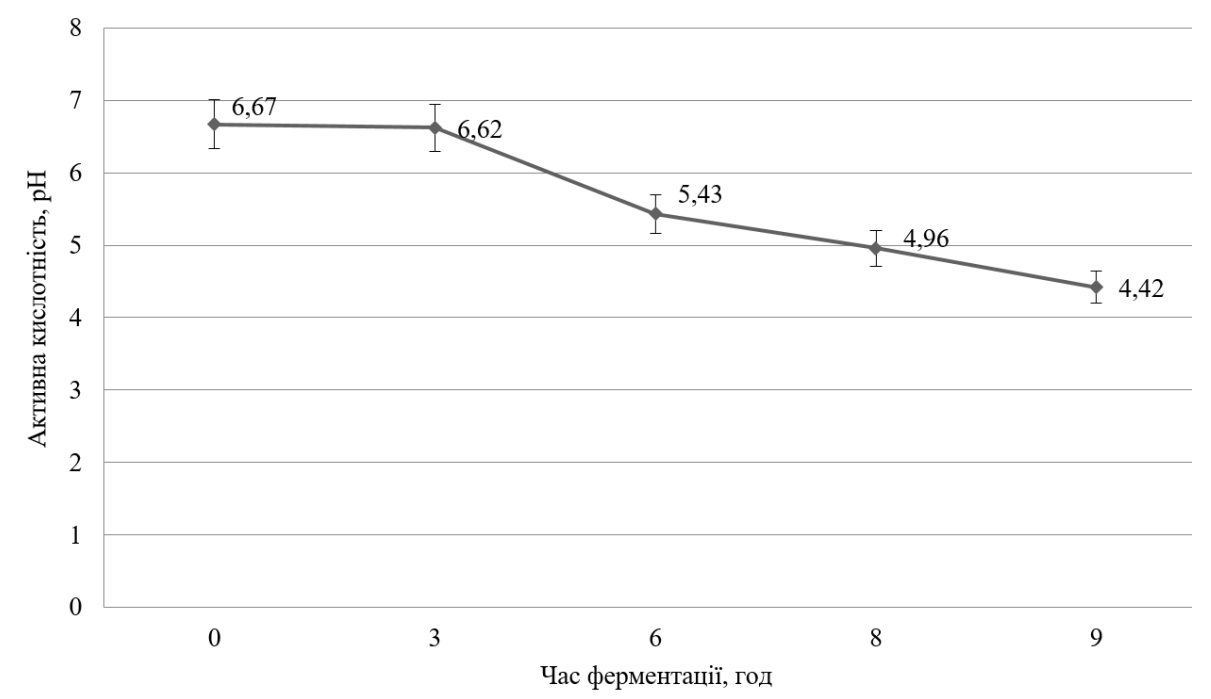

Рис. 3. Активна кислотність (рН) у контрольних зразках кефіру впродовж процесу ферментації $(\mathrm{M} \pm \mathrm{m}, \mathrm{n}=5)$

Як видно із даних, наведених на рис. 3, на початку процесу сквашування активна кислотність (pH) у контрольних зразках кефіру становив 6,67. В процесі сквашування активна кислотність (рН) у контрольних зразках кефіру закономірно знижувався і в кінці дослідження, тобто через 9 годин становила 4,43. Така динаміка зміни активної кислотності під час сквашування контрольних зразків кефіру в кислу сторону $є$ адекватним процесом, який відповідає нормативним положенням.

На рис. 4 наведені результати дослідження активної кислотності у дослідних зразках кефіру 3 біологічно активним йодом впродовж процесу ферментації.

Як видно із даних, наведених на рис. 4, нами встановлена аналогічна тенденція зменшення активної кислотності (pH) у дослідних зразках кефіру, як і в контрольних зразках із різницею в межах достовірної похибки. Так, на початку процесу сквашування активна кислотність у дослідних зразках кефіру 3 біологічно активним йодом становив 6,66, а на завер- шенні експерименту, тобто через 9 годин становила 4,42. Таким чином, згідно 3 даними, наведеними в таблиці 7, спостерігаємо інтенсивне зменшення активної кислотності під час процесу сквашування в досліджуваних зразках кефіру з біологічно активним йодом. Отримані результати дослідження активної кислотності у контрольних і дослідних зразках кефіру свідчать про відсутність впливу біологічно активного йоду з "Йодіс-концентрат" на динаміку змін активної кислотності (рH).

Окрім титрованої кислотності та активної кислотності (pH), проводилося визначення зміни в'язкості кефіру без біологічно активного йоду (контроль), та 3 додаванням біологічно активного йоду (дослід). Дослідження проводилися на етапі перемішування продукту після етапу сквашування. Визначення в'язкості кефіру визначали за допомогою піпетки, методом вільного падіння. Температура кефіру при цьому становила $20^{\circ} \mathrm{C}$, об'єм піпетки 100 мл. Результати досліджень контрольних та дослідних зразків наведена в таблиці 4. 


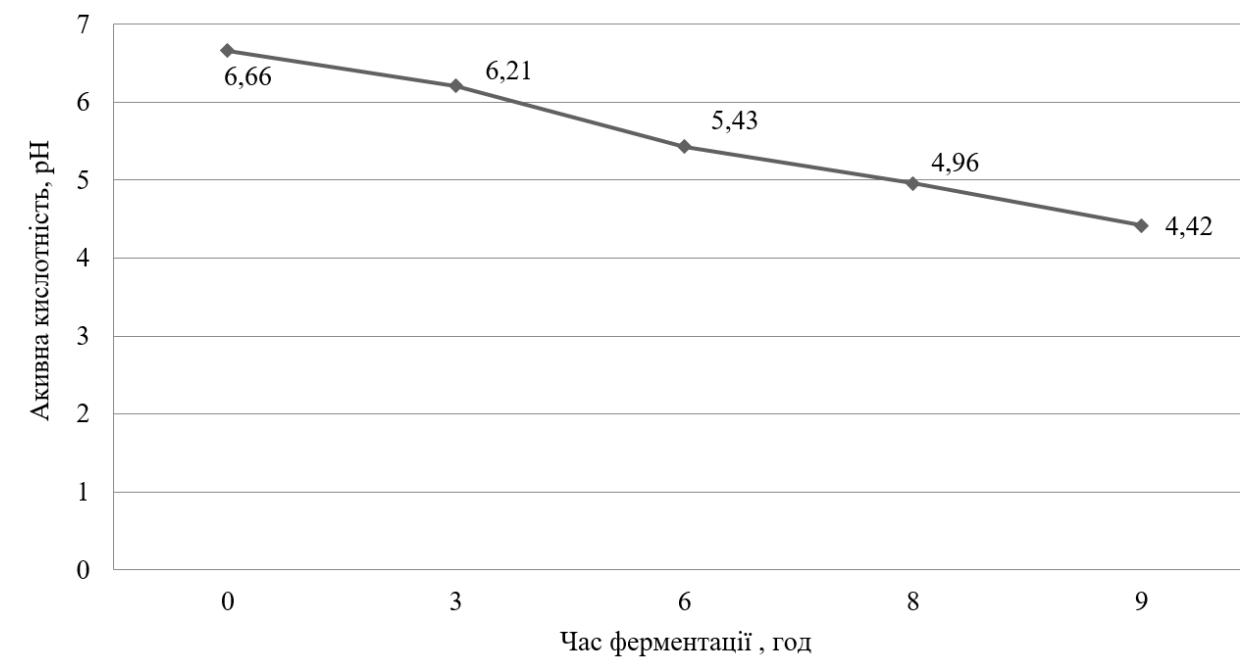

Рис. 4. Активна кислотність (pH) у дослідних зразках кефіру впродовж процесу ферментації $(\mathrm{M} \pm \mathrm{m}, \mathrm{n}=5)$

\section{Таблиця 4}

Результати дослідження в'язкості кефіру у контрольних та дослідних зразках (M $\pm \mathrm{m}, \mathrm{n}=5)$

\begin{tabular}{lccc}
\hline & Назва зразків & Результат дослідження (с.) & Відхилення (с.) \\
\hline Контроль & 15 & \pm 1 \\
Дослід & 15 & \pm 1 \\
\hline
\end{tabular}

Згідно даних, наведених в таблиці 4 , зміни в'язкості кефіру в контрольних та дослідних зразках немає. Тобто біологічно активна добавка "Йодісконцентрат" не впливає на в'язкість кефіру.
Після етапу перемішування кефіру проводилося дослідження масової частки жиру, згідно чинних нормативних документів наведених в таблиці 2. Результати дослідження наведені в таблиці 5.

\section{Таблиця 5}

Результати дослідження масової частки жиру у контрольних та дослідних зразках кефіру $(\mathrm{M} \pm \mathrm{m}, \mathrm{n}=5)$

\begin{tabular}{lccc}
\hline & Назва зразків & Результат дослідження (\%) & Відхилення (\%) \\
\hline Контроль & 2,5 & $\pm 0,1$ \\
Дослід & 2,5 & $\pm 0,1$ \\
\hline
\end{tabular}

Отримані результати, які зазначені в таблиці 5, свідчать про відсутність впливу "Йодіс-концентрат" на значення масової частки жиру.

\section{Обговорення}

Україна належить до ендемічної зони йододефіциту. Потреба в йодовмісних продуктах зростає відповідно $з$ кількістю дорослих та дітей із захворюваннями щитоподібної залози.

Молочна промисловість зменшує виробництво кисломолочних продуктів у зв'язку зі зменшенням попиту. Молочні продукти є важливим компонентом здорового харчування та забезпечення функціонування мікрофлори кишечника. Для підтримання всіх функціональних властивостей організму ми повинні вживати правильні й потрібні продукти харчування. Кефір 3 біологічно активною добавкою "Йодісконцентрат" додасть нашому організму життево необхідний мікроелемент - Йод, а корисна мікрофлора кисломолочного продукту допоможе роботі травної системи. Добова потреба Йоду коливається від 100 до 300 мкг/добу, з розрахунком цього показника вживання представленого продукту потрібне щодня.
Згідно 3 проведеними дослідженнями, “Йодісконцентрат" не впливає на фізико-хімічні показники кефіру, тим самим зберігає всі його корисні властивості.

\section{Висновки}

1. Проведено порівняльні дослідження окремих фізико-хімічних показників, а саме титрованої кислотності та водневого показника у контрольних (без добавок) i дослідних (з добавкою біологічно активного йоду з “Йодіс-концентрат") зразках кефіру в процесі сквашування.

2. Встановлено, що титрована кислотність в обох зразках кефіру - контрольному і дослідному мала однакову динаміку до зростання в процесі сквашування, що свідчить про відсутність впливу додавання біологічно активного йоду на динаміку титрованої кислотності.

3. Встановлена однакова тенденція зменшення $\mathrm{pH}$ у контрольних і дослідних зразках кефіру в процесі сквашування із різницею в межах достовірної похибки, що свідчить про відсутність впливу дода- 
вання біологічно активного йоду до кефіру на водневий показник.

4. Встановлено, що біологічно активна добавка “Йодіс-концентрат” не впливає на в'язкість кефіру.

5. Встановлено, що біологічно активний йод в складі добавки "Йодіс-концентрат" не впливає на масову частку жиру.

\section{References}

Cais-Sokolinska, D. Danków, R., \& Pikul, J. (2008). Physicochemical and sensory characteristics of sheep kefir during storage. Acta Science Polonium, Technol. Aliment, 7(2), 63-73. URL: https://www.food.actapol. net/pub/6_2_2008.pdf.

Ctarovoitova, A. A. (2017). Mikrobiolohiia moloka i molochnykh produktiv. Bila Tserkva(in Ukrainian).

DSTU 4417 Kefir. Zahalni tekhnichni umovy (in Ukrainian).

DSTU 6066 Moloko ta molochni produkty. Metodyky vyznachannia temperatury (in Ukrainian).

DSTU 6082 Moloko ta molochni produkty. Metody vyznachannia hustyny (in Ukrainian).

DSTU 8550 Moloko ta molochni produkty. Vymiriuvannia $\mathrm{pH}$ potentsiometrychnym metodom (in Ukrainian).

DSTU ISO 1211 Moloko. Hravimetrychnyi metod vyznachennia vmistu zhyru (kontrolnyi metod) (ISO 1211:1999, IDT) (in Ukrainian).

DSTU ISO 707 Moloko ta molochni produkty. Nastanovy z vidbyrannia prob (ISO 707:1997, IDT). (in Ukrainian).

Haidei, O., Shuliak, S., Oleksiienko, I., Kyivska, G., \& Krushelnytska, O. (2020). Monitoring of gluten in dairy products. Scientific Messenger of LNU of Veterinary Medicine and Biotechnologies. Series: Food Technologies, 22(94), 8-12. doi: 10.32718/nvlvetf9402.

HOST 3624 Moloko ta molochni produkty. Tytrametrychnyi metod vyznachennia kyslotnosti (in Ukrainian).

Kopchak, N. H., Pokotylo, O. S., Kukhtyn, M. D., \& Koval, M. I. (2017). Vplyv yodu na pokaznyky lipidnoho profiliu krovi shchuriv riznoho viku pry eksperymentalnomu ozhyrinni. Medychna ta klinichna khimiia, 4, 123-128 (in Ukrainian).
Kopchak, N. H., Pokotylo, O. S., Kukhtyn, M. D., Yaroshenko, T. Ya., Kulitska, M. I., \& Bandas, I. A. (2018). Age and sex characteristics of thyroxine and triiodothyronine content in the blood of white rats with experimental alimentary obesity under the influence of iodine. Research Journal of Pharmaceutical, Biological and Chemical Sciences, 9(5), 2392-2397. URL: https://www.rjpbcs.com/pdf/ 2018 9(5)/[304].pdf.

Korzun, V. N., Vorontsova, T. O., \& Antoniuk, I. Iu. (2018). Ekolohiia i zakhvoriuvannia shchytopodibnoi zalozy. Medinform (in Ukrainian).

Nagovska, V. O., Hachak, Yu. R., Bilyk, O. Ya., Gutyj, B. V., Slyvka, N. B., \& Mikhailytska, O. R. (2018). Influence of thistle grist on organoleptic, physicochemical and microbiological parameters of kefir. Scientific Messenger of Lviv National University of Veterinary Medicine and Biotechnologies, 20(85), 166-170. doi: 10.15421/nvlvet8530.

Nahovska, V., Hachak, Y., MyhaylytskaO., \& Slyvka, N. (2017). Application of wheat brans as a functional ingredient in the technology of kefir. Scientific Messenger of LNU of Veterinary Medicine and Biotechnologies. Series: Food Technologies, 19(80), 52-56. doi: 10.15421/nvlvet8011.

Nechyporuk, V. M., \& Korda, M. M. (2015). Metabolizm pry hipo- ta hipertyreozi. Visnyk naukovykh doslidzhen, 3, 4-7 (in Ukrainian).

Norouzian, M. A. (2011). Iodine in raw and pasteurized milk of dairy cows fed different amounts of potassium iodide. Biol Trace Elem Res, 139(2), 160-167. doi: 10.1007/s12011-010-8651-z.

Sojustova, E. L., Klimenko, L. L., \& Deev, A. I. (2009). Disfunkcija shhitovidnoj zhelezy u lic starshih vozrastnyh grupp. Klin. Gerontol, 1, 72-75 (in Russian).

Soriguer, F., Gutierrez-Repiso, C., Gonzalez-Romero, S., et al. (2011). Iodine concentration in cow's milk and its relation with urinary iodine concentrations in the population. Clin Nutr, 30(1), 44-48. doi: 10.1016/j.clnu.2010.07.001

Yukalo, V., Datsyshyn, K., \& Storozh, L. (2019). Comparison of products of whey proteins concentrate proteolysis, obtained by different proteolytic preparations. Eastern-European Journal of Enterprise Technologies, 5(11(101), 40-47. doi: 10.15587/17294061.2019.177314 